\title{
Pancreatic metastases from renal cell carcinoma: a case report and literature review of the clinical and radiological characteristics
}

\author{
Yoshinori Hoshino ${ }^{1 *}$, Hiroharu Shinozaki ${ }^{1}$, Yuki Kimura ${ }^{1}$, Yohei Masugi ${ }^{2}$, Homare Ito ${ }^{1}$, Toshiaki Terauchi ${ }^{1}$, \\ Masaru Kimata' ${ }^{1}$, Junji Furukawa' ${ }^{1}$ Kenji Kobayashi ${ }^{1}$ and Yoshiro Ogata ${ }^{1}$
}

\begin{abstract}
Metastatic pancreatic cancer is rare, accounting for approximately $2 \%$ of all pancreatic malignancies, and most cases arise from renal cell carcinoma. We report the case of a 63-year-old woman, who presented with a pancreatic tumor detected during her annual health examination. She had undergone left nephrectomy 13 years previously for renal cell carcinoma. Computed tomography (CT) revealed two tumors in the head and body of the pancreas, a hypervascular tumor and a hypovascular tumor with an enhanced rim, respectively. She underwent pylorus-preserving pancreaticoduodenectomy, and metastatic pancreatic tumors arising from the kidney with clustered clear cell carcinoma immunohistochemically positive for CD10 were diagnosed. This report presents the different enhancement features of different lesions on CT scans. Because the enhancement features of lesions have been reported to vary according to the size of the metastatic tumor, a knowledge of the history of renal cell carcinoma is crucial for diagnosis.
\end{abstract}

Keywords: Pancreatic metastasis, Surgery, Renal cell carcinoma, Imaging, Radiological characteristics

\section{Background}

Isolated metastasis to the pancreas is rare, ranging in incidence from $2 \%$ to $5 \%$ in clinical studies [1-6]. Renal cell carcinoma (RCC), melanoma, lung cancer, colorectal cancer and breast cancer are known to metastasize to the pancreas [7-11]. Most patients with pancreatic metastases are asymptomatic, whereas some exhibit jaundice or abdominal pain [12]. RCC has an annual incidence of more than 30,000 a year in the United States, and localized disease is treated via nephrectomy. Of patients with pancreatic metastases, $12 \%$ present with synchronous extrapancreatic metastasis, and they have a poor prognosis $[13,14]$. However, surgical treatment for isolated metachronous pancreatic metastases from RCC has been reported in recent years to improve prognosis [6,13-17]. In this study, we report a case of pancreatic metastases from RCC with different radiographic patterns for each lesion and review the radiographic

\footnotetext{
*Correspondence: ymailbiz@gmail.com

'Department of Surgery, Saiseikai Utsunomiya Hospital, 911-1 Takebayashi, Utsunomiya 321-0974, Japan

Full list of author information is available at the end of the article
}

patterns of pancreatic metastases using computed tomography (CT) and fluorodeoxyglucose (FDG)-positron emission tomography (PET).

\section{Case presentation}

A 63-year-old woman had undergone left nephrectomy for RCC at our hospital 13 years previously. After 5 consecutive years of follow-up, she underwent an annual medical examination. Abdominal ultrasonography (US) revealed an abnormal mass in the body of the pancreas. CT revealed two lesions: a low-density mass $(15 \mathrm{~mm}$ in diameter) in the pancreatic body that displayed rim enhancement and a homogeneously enhanced mass $(8 \mathrm{~mm}$ in diameter) in the head (Figure 1). Magnetic resonance imaging (MRI) did not show enhancement in either lesion. FDG-PET did not show any abnormal metabolic activity in the pancreas. To allow a pathological diagnosis, endoscopic ultrasonography (EUS)-guided fine-needle aspiration biopsy was performed, but only necrotic tissue was obtained from the specimen. Although the radiographic features of the lesions were different, pancreatic metastases from RCC were strongly suspected because of the 


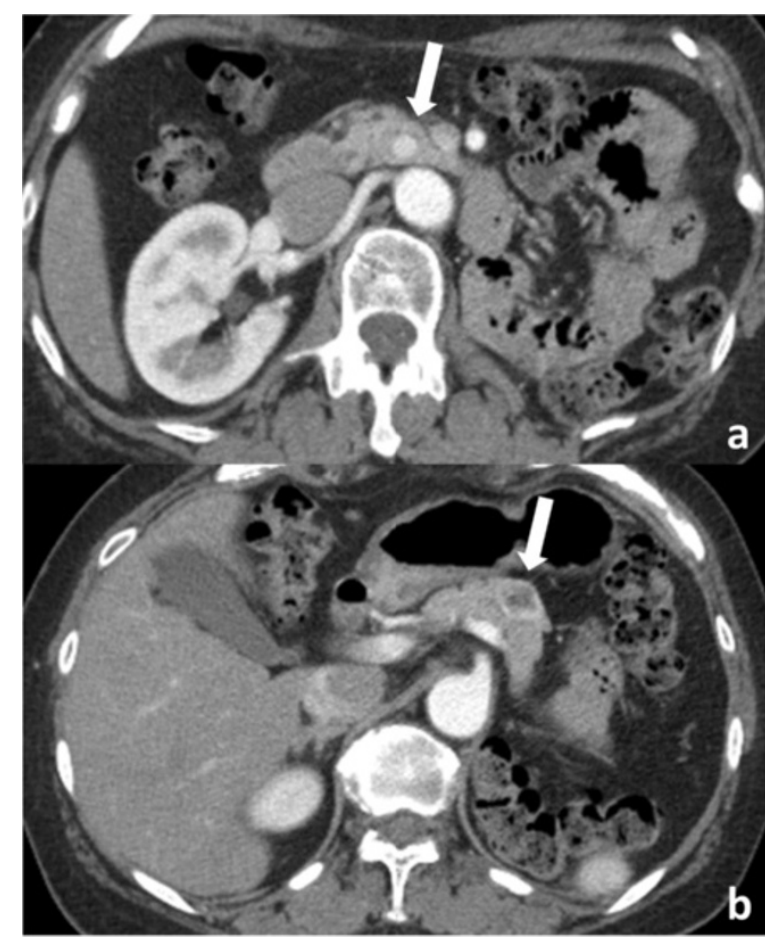

Figure $1 \mathrm{CT}$ findings of the pancreatic metastases (arrows). a. Homogenous hypervascular head lesion. b. body lesion with central necrosis and enhanced rim patient's history of RCC. We noted the following from the laboratory findings: DUPAN-2, $<25 \mathrm{U} / \mathrm{ml}$ (normal, $<25 \mathrm{U} / \mathrm{ml}$ ); Span-1, $2.3 \mathrm{U} / \mathrm{ml}$ (normal, $<30 \mathrm{U} / \mathrm{ml}$ ); carcinoembryonic antigen, $1.7 \mathrm{ng} / \mathrm{ml}$ (normal, $<5.0 \mathrm{ng} / \mathrm{ml}$ ); carbohydrate antigen 19-9, $2.6 \mathrm{U} / \mathrm{ml}$ (normal, <37 U/ml) and gastrin, $480 \mathrm{pg} / \mathrm{ml}$ (normal, $<200 \mathrm{pg} / \mathrm{ml}$ ). The patient underwent pylorus-preserving pancreaticoduodenectomy using the Imanaga method [18]. For the R0 resection, an extended pancreaticoduodenectomy was required rather than a classical resection. Intraoperative US revealed a low echoic mass with a bright halo and peripherally enriched blood flow in the body and a low echoic mass with homogeneously enriched blood flow in the head. Gross pathological examination revealed a $15 \mathrm{~mm} \times 13 \mathrm{~mm}$ tumor occupying the body of the pancreas and another $8-\mathrm{mm}$ tumor in the uncinate process of the pancreas. The head lesion was soft, whereas the body lesion was firm in consistency. The cut surface of the head lesion was yellow, whereas that of the lesion in the pancreatic body was grayish-white. Metastatic tumor cells homogeneously occupied the tumor in the head of the pancreas, and the firm lesion in the body of the pancreas showed a necrotic change in the center, which was surrounded by viable tumor cells and a fibrous capsule, identified as a low-density area on a CT scan (Figure 2). Immunohistochemically, the tumors were positive for CD10 and negative for chromogranin A and synaptophysin (Figure 2). Microscopic examination revealed large epithelial cells with clear cytoplasm and eosinophilic nuclei arranged in alveolar structures with abundant vascularity (Figure 3a). In addition, histological examination revealed another 1-mm occult micrometastatic lesion in the head of the pancreas (Figure 3b). The harvested lymph nodes and surgical margins were free of malignancy. Taken together, the pathological findings indicated that the lesions were metastases from RCC, and the thick enhanced rim of the body lesion was believed to be composed of viable RCC cells with high vascularity. The postoperative course was uneventful, and to date the patient has survived for 6 months without any evidence of recurrence or metastasis.

\section{Discussion}

RCC accounts for approximately $2 \%$ of all adult malignances. Among kidney-limited diseases, RCC has a high overall survival rate (up to 95\%) [19]. However, 20\% to $30 \%$ of patients have metastases at presentation, and the 5 -year survival rate is less than $10 \%$ once metastases spread [20]. In studies of resected specimens, RCC was the most common primary tumor leading to isolated pancreatic metastases $[6,15]$. RCC recurrence is classified as early or late recurrence. Late recurrence after nephrectomy is not common: recurrence is seen in $10 \%$ of patients after more than 10 years after surgery [21]. In most studies, the development of pancreatic metastasis was observed after a disease-free period after nephrectomy exceeding 10 years (maximum, 32.7 years) [22]. The relation between the metastatic location of the pancreas and the primary RCC is controversial [23] and can be either hematogeneous or via lymphatics [24]. Hematogeneous spread may occur along the draining collateral vein of a hypervascular renal tumor, and the spread through lymphatics may occur by retrograde lymph flow secondary to tumor infiltration of the retroperitoneal lymph nodes [25].

The symptoms of pancreatic metastasis are often nonspecific. Sellner et al. [13] reported in a review of 236 cases that $35 \%$ of patients were asymptomatic, whereas other patients had abdominal pain (20\%), gastrointestinal tract bleeding (20\%), obstructive jaundice (9\%), weight loss $(9 \%)$, pancreatitis $(3 \%)$ or diabetes mellitus (3\%). The diameter of the metastatic lesion was reported to have some association with patient symptoms. Bassi et al. [26] reported that the median tumor diameter in asymptomatic patients was $25 \mathrm{~mm}$, compared to $45 \mathrm{~mm}$ in symptomatic patients. Conversely, Reddy et al. [27] reported that 93\% (42/45) of patients had symptoms such as abdominal pain, jaundice or weight loss.

In general, the preoperative diagnosis of pancreatic metastases begins with a suspicion based on the patient's 


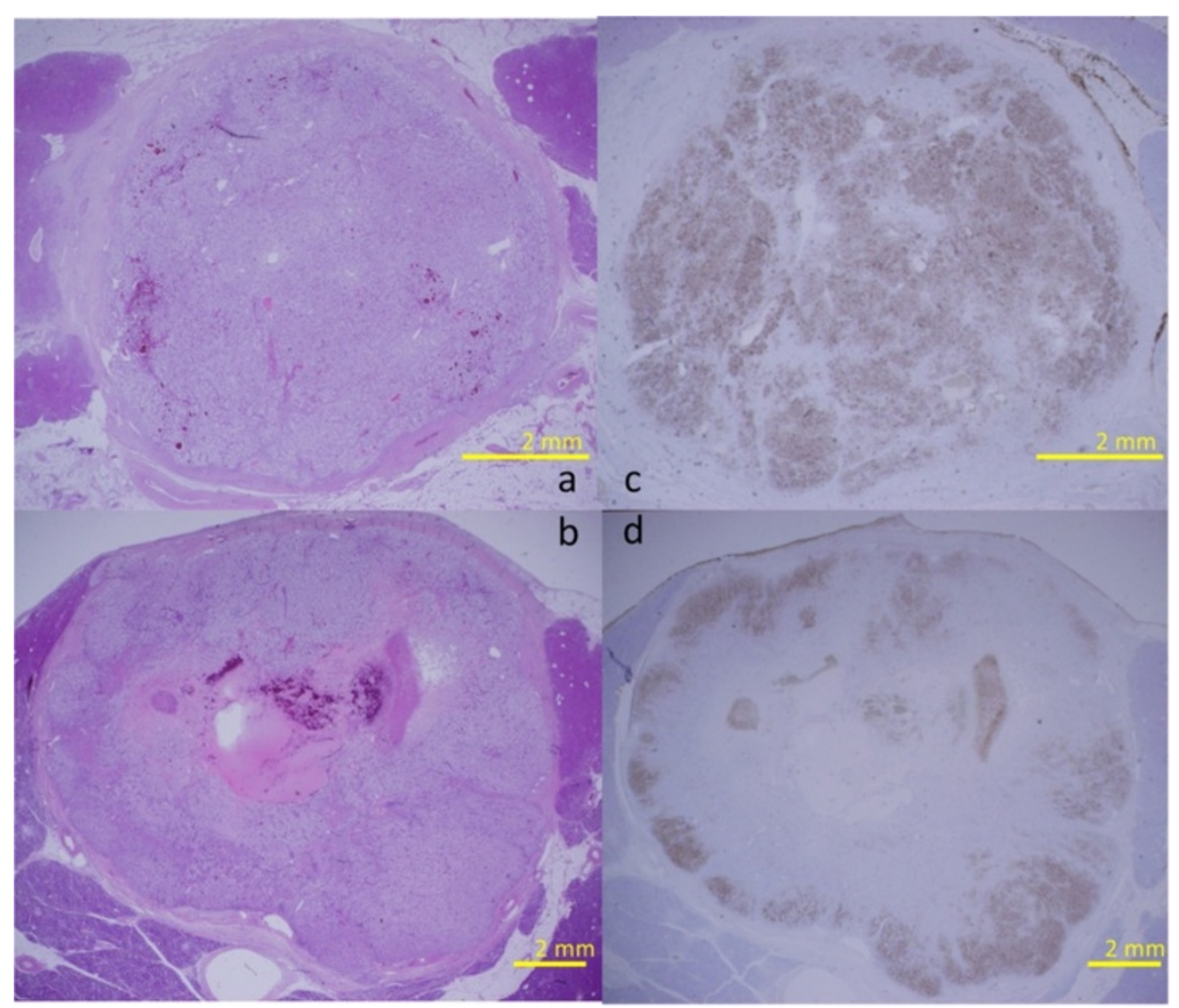

Figure 2 Loupe images of resected specimen. The head lesion (a.c.) consist of tumor cells, whereas the body with necreotic change in the center. a.c. Head lesion with hypervascular attenuation (a; H.E. stain, $\mathbf{c} ;$ CD10). b.d. Body lesion with central hypodense (b; H.E. stain, d; CD10).

history [28]. Imaging modalities such as CT, MRI, FDGPET and EUS support the diagnosis. Muranaka et al. [29] reviewed the CT findings of pancreatic metastases from 28 metastatic carcinomas and classified these into 3 types according to their configuration: (1) a single localized metastasis (50\% to 73\%) [29-31]; (2) a diffuse enlargement with homogeneous attenuation of the pancreas $(15 \%$ to $44 \%$ ) [29-31] and (3) multifocal metastases (5\% to $10 \%)$ [29-31]. Metastases from RCC are usually hypervascular and consequently display homogeneous contrast medium enhancement in the arterial phase of CT. Hyperenhancement of pancreatic metastases from RCC plays an important role in both the detection of tumor locations and the distinction of metastases from primary adenocarcinoma of the pancreas [32]. When hypervascular pancreatic tumors are identified on enhanced CT scans, differentiation from primary pancreatic endocrine tumors, intrapancreatic accessory spleens and vascular lesions is difficult. Palmowski et al. [4] observed two types of enhancement on CT scans of pancreatic metastases, namely lesions with either a homogeneous enhancement or a highlighted rim and nonenhancing internal components, depending on the size. In lesions greater than $15 \mathrm{~mm}$ in size, rim enhancement with hypodense central areas of necrosis has been observed on CT scans [32]. This hypodense aspect is associated with colonic metastases, hyperdense attenuation with RCC, or breast cancer [33,34]. We reviewed the radiological features of pancreatic metastases from RCC shown by dynamic CT scans (Table 1). Of 66 patients, 45 (68\%) had homogeneous hypervascular enhancement features, whereas 21 (32\%) had central hypovascularity with rim enhancement. Of these, 31 patients had a metastatic configuration, 5 patients had multifocal metastases to the pancreas and 26 patients had solitary tumors. No patients with pancreatic metastasis from RCC developed diffuse enlargement of the pancreas. In the present review, the size of pancreatic metastases from RCC has no particular relation with the presence of central hypodense areas because even tumors $>5 \mathrm{~cm}$ in size displayed hypervascular attenuation. The present case was classified as one with multifocal metastases in terms of the metastatic location. To our knowledge, this is the first case of concomitant multifocal metastases featuring two different enhancement characteristics, hypodense areas and homogenous hypervascularity.

FDG-PET has not been established for the diagnosis of metastatic RCC. Ramdave et al. [45] reported that FDGPET was useful for identifying distant metastases from 


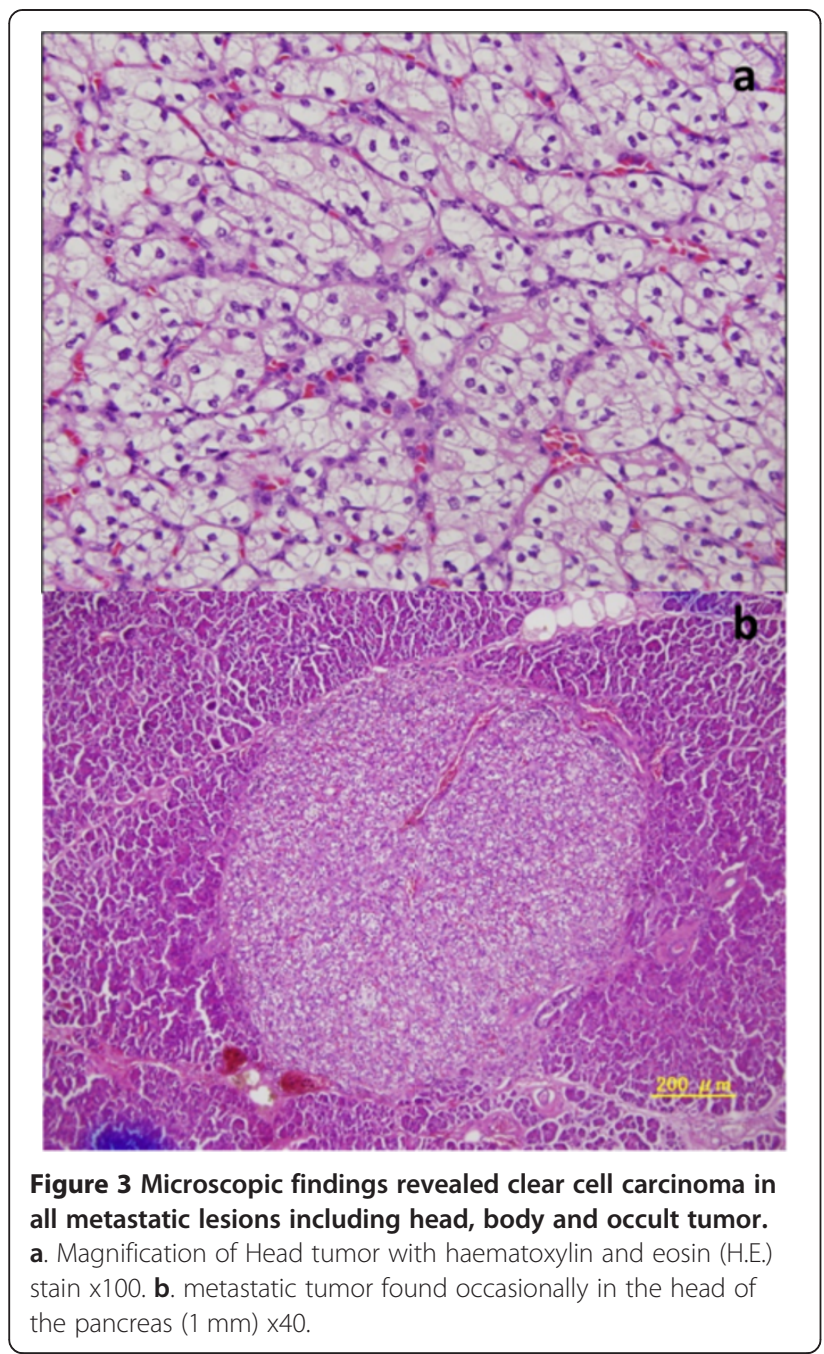

RCC in all six of the patients in the study. Majhail et al. [46] calculated the sensitivity and specificity of FDGPET for identifying distant metastases from RCC. They revealed that the sensitivity of the procedure was linked to the size of the metastases $(83 \%$ for lesions larger than $15 \mathrm{~mm}$; 93\% for those larger than $20 \mathrm{~mm}$ ). In the present patient with 15- and 8-mm lesions, FDG did not indicate any abnormal metabolic activity in either lesion.

Surgical resection of the pancreas is associated with substantial morbidity after surgery, and the survival benefit of surgery for metastatic lesions of the pancreas remains questionable since randomized control trials have not been conducted. However, surgical resection of metastatic deposits of RCC remains the most effective treatment because chemotherapy, immunotherapy and radiotherapy have generally proved to be ineffective for metastatic RCC [14,22,25,47]. We reviewed studies published from 1998 to 2013 that focused on surgical resection of the pancreas for metastases from RCC. The survival rates and features are listed in Table 2. The median 5-year overall survival rate after metastasectomy was reported to be $75 \%$ to $88 \%$, compared to $0 \%$ to $50 \%$ without metastasectomy $[13,14,17]$. In a review, Masetti et al. [48] analyzed data for 159 patients who underwent metastasectomy of the pancreas for RCC: the median survival and 5-year survival rate were 5.8 years and $63.5 \%$, respectively. Tanis et al. [49] reviewed 170 articles, and data for a total of 411 patients who underwent resection of pancreatic metastases were analyzed. They reported a pancreatic recurrence rate of $4.0 \%$ after a median of 42 months and an extrapancreatic recurrence rate of $17.1 \%$. The 5 -year survival rate was $72.6 \%$. The surgical mortality rate after pancreaticoduodenectomy for pancreatic metastases was reported to be $2.6 \%$ [23]. Sellner et al. [13] compared the 5-year overall survival rate of patients with a solitary metastasis with those with multiple metastases (solitary metastasis, 64\%; multiple metastases, 78\%). Combining the findings outlined in several reports [50-52], radical surgery for multifocal metastases from RCC in the pancreas appears to be as justified as that for a solitary metastasis. Radical surgery with the R0 resection is the only curative option for patients with pancreatic metastases. Therefore, surgical resection for pancreatic metastases should be considered under individualized conditions including the management of comorbidities.

\section{Conclusions}

Multifocality of pancreatic metastasis has been reported to be in the range $20 \%$ to $45 \%[13,14]$. In one report, a preoperative multifocality detection of $17.4 \%$ increased up to $34.8 \%$ on pathological examination of resected specimens [14]. Here, we report a rare case of pancreatic metastases with micrometastasis, which was not detected preoperatively, in the resected pancreas specimen on pathological examination. Moreover, pancreatic metastases from RCC can show both hypervascular attenuation and are central hypodense on CT scans although they are generally hypervascular tumors. Careful examination with multiple modalities for the diagnosis of the metastatic configuration and follow-up are recommended after surgery.

\section{Consent}

Written informed consent was obtained from the patient for publication of this case report and any accompanying images. A copy of the written consent is available for review by the Editor-in-Chief of this journal. 
Table 1 Radiologic features of pancreatic metastases from renal cell carcinoma shown by computed tomography

\begin{tabular}{|c|c|c|c|c|c|c|}
\hline \multirow[t]{3}{*}{ Reference } & \multirow[t]{3}{*}{ Year } & \multicolumn{5}{|c|}{ Number of patients } \\
\hline & & \multicolumn{2}{|c|}{ Enhancement features } & \multirow[b]{2}{*}{ Total } & \multicolumn{2}{|c|}{$\begin{array}{l}\text { Imaging } \\
\text { configuration }\end{array}$} \\
\hline & & $\begin{array}{l}\text { Homogeneous } \\
\text { hypervascularity }\end{array}$ & $\begin{array}{l}\text { Central hypodense areas } \\
\text { with rim enhancement }\end{array}$ & & Solitary & Multiple \\
\hline Marunaka et al. [29] & 1989 & 1 & 0 & 1 & 1 & 0 \\
\hline Boudghene et al. [33] & 1994 & 3 & 2 & 5 & NA & NA \\
\hline Scatarige et al. [35] & 2001 & 1 & 1 & 2 & 2 & 0 \\
\hline Faure et al. [36] & 2001 & 5 & 3 & 8 & NA & NA \\
\hline Yachida et al. [37] & 2002 & 1 & 0 & 1 & 1 & 0 \\
\hline Zacharoulis et al. [38] & 2003 & 3 & 0 & 3 & 2 & 1 \\
\hline David et al. [25] & 2006 & 0 & 1 & 1 & 1 & 0 \\
\hline Palmowski et al. [4] & 2008 & 12 & 10 & 22 & NA & NA \\
\hline Mecho et al. [39] & 2009 & 4 & 2 & 6 & 6 & 0 \\
\hline You et al. [40] & 2011 & 2 & 0 & 2 & 0 & 2 \\
\hline Katsourakis et al. [41] & 2012 & 1 & 0 & 1 & 1 & 0 \\
\hline Atiq et al. [42] & 2012 & 2 & 2 & 4 & 3 & 1 \\
\hline Comunoglu et al. [43] & 2012 & 1 & 0 & 1 & 0 & 1 \\
\hline Yazbek et al. [44] & 2012 & 9 & 0 & 9 & 9 & 0 \\
\hline Totals & & 45 & 21 & 66 & 26 & 5 \\
\hline
\end{tabular}

NA, not available.

Table 2 Literature review of surgical treatment for pancreatic metastases from RCC

\begin{tabular}{|c|c|c|c|c|c|c|c|c|}
\hline Reference & Year & $\begin{array}{l}\text { Number of } \\
\text { patients }^{\mathrm{a}}\end{array}$ & Median age & Sex (F:M) & $\begin{array}{l}\text { 5-year } \\
\text { survival }\end{array}$ & $\begin{array}{c}\text { Median } \\
\text { survival (months) }\end{array}$ & $\begin{array}{l}\text { Time from primary } \\
\text { treatment (months) }\end{array}$ & $\begin{array}{l}\text { Median follow-up } \\
\text { period (months) }\end{array}$ \\
\hline Butturini et al. [53] & 1998 & 5 & 63 & $2: 3$ & NA & 24.5 & $120(24-276)$ & 19 \\
\hline Kassabian et al. [54] & 2000 & 5 & 56 & $1: 4$ & $67 \%$ & NA & $144(48-180)$ & 48 \\
\hline Ghavamian et al. [55] & 2000 & 11 & 68 & $3: 8$ & $81 \%$ & 120 & 108 (18-295) & 50 \\
\hline Sohn et al. [17] & 2001 & 10 & 63 & $4: 6$ & $80 \%$ & 7 & $102(0-336)$ & 8 \\
\hline Faure et al. [36] & 2001 & 8 & 57 & $2: 6$ & $88 \%$ & NA & $83(12-120)$ & 38 \\
\hline Yachida et al. [37] & 2002 & 5 & 60 & $2: 3$ & $100 \%$ & 12 & 144 (36-288) & 18 \\
\hline Law et al. [56] & 2003 & 14 & 64 & $9: 5$ & $75 \%$ & NA & $78(0-300)$ & 130 \\
\hline Wente et al. [47] & 2005 & 15 & 63 & $10: 5$ & NA & NA & $85(0-258)$ & 10 \\
\hline Crippa et al. [6] & 2006 & 5 & 65 & $3: 2$ & $80 \%$ & NA & $36(22-192)$ & 41 \\
\hline Eidt et al. [15] & 2007 & 7 & 64 & $2: 5$ & $88 \%$ & NA & $160(108-240)$ & 36 \\
\hline Varker et al. [57] & 2007 & 5 & NA & NA & $60 \%$ & NA & 175 & NA \\
\hline Schauer et al. [58] & 2008 & 10 & 62 & $5: 5$ & $60 \%$ & 33 & $128(5-277)$ & 56 \\
\hline Zerbi et al. [14] & 2008 & 23 & 64 & $15: 8$ & $88 \%$ & 27 & $96(12-276)$ & 31 \\
\hline Reddy et al. [27] & 2008 & 21 & 60 & $11: 10$ & $45 \%$ & 58 & 110 & over 120 \\
\hline Tanis et al. [49] & 2009 & 10 & 63.5 & $2: 8$ & NA & NA & $107(5-228)$ & NA \\
\hline Masetti et al. [48] & 2010 & 6 & 62 & $6: 0$ & NA & NA & $57.6(20-288)$ & 3 \\
\hline Konstantinidis et al. [59] & 2010 & 20 & 68.5 & $7: 13$ & $61 \%$ & 104 & 104 & NA \\
\hline Yazbek et al. [44] & 2012 & 11 & 73 & $1: 10$ & $90 \%$ & 84 & $136(12-240)$ & NA \\
\hline Gardini et al. [60] & 2012 & 8 & 68 & $4: 4$ & NA & NA & NA & 38.6 \\
\hline
\end{tabular}

NA: not available.

${ }^{\text {a }}$ Studies that included less than four patients were excluded. 


\section{Abbreviations}

CT: Computed tomography; EUS: Endoscopic ultrasonography; FDG: Fluorodeoxyglucose; HE: Hematoxylin and eosin; MRI: Magnetic resonance imaging; PET: Positron emission tomography; RCC: Renal cell carcinoma; US: Ultrasonography.

\section{Competing interests}

The authors declare that they have no competing interests.

\section{Authors' contributions}

$\mathrm{YH}$ performed the majority of this study and drafted the manuscript. YK, $\mathrm{HI}$, YM, and TT surveyed the literature. JF and MK critically revised the manuscript. HS, KK, and $\mathrm{YO}$ participated in the design and interpretation of this study under supervision. All authors read and approved the final manuscript.

\section{Acknowledgements}

We are grateful to Nobuhiro Nishizawa for his dedicated work in the patien management

\section{Author details}

'Department of Surgery, Saiseikai Utsunomiya Hospital, 911-1 Takebayashi, Utsunomiya 321-0974, Japan. ²Department of Pathology, Keio University, School of Medicine, 35 Shinanomachi, Tokyo 165-8582, Japan.

Received: 29 May 2013 Accepted: 25 October 2013

Published: 9 November 2013

\section{References}

1. Bonapasta SA, Gregori M, Lanza R, Sangiorgi E, Menghi A, Scarpini M, Modesti M: Metastasis to the pancreas from breast cancer: difficulties in diagnosis and controversies in treatment. Breast Care (Basel) 2010, 5:170-173.

2. Blazer DG 3rd, Ramirez PT, Wang H, Fleming JB: Distal pancreatectomy for isolated metastasis of endometrial carcinoma to the pancreas. JOP 2008 9:56-60.

3. Hernandez S, Martin-Fernandez J, Lasa I, Busteros I, Garcia-Moreno F: Pancreaticoduodenectomy for metastasis of uterine leiomyosarcoma to the pancreas. Clin Transl Oncol 2010, 12:643-645.

4. Palmowski M, Hacke N, Satzl S, Klauss M, Wente MN, Neukamm M, Kleeff J, Hallscheidt P: Metastasis to the pancreas: characterization by morphology and contrast enhancement features on CT and MRI. Pancreatology 2008, 8:199-203.

5. Sperti C, Pasquali C, Berselli M, Frison L, Vicario G, Pedrazzoli S: Metastasis to the pancreas from colorectal cancer: is there a place for pancreatic resection? Dis Colon Rectum 2009, 52:1154-1159

6. Crippa S, Angelini C, Mussi C, Bonardi C, Romano F, Sartori P, Uggeri F, Bovo G: Surgical treatment of metastatic tumors to the pancreas: a single center experience and review of the literature. World J Surg 2006, 30:1536-1542.

7. Roland CF, van Heerden JA: Nonpancreatic primary tumors with metastasis to the pancreas. Surg Gynecol Obstet 1989, 168:345-347.

8. Lopez-Cantarero Ballesteros M, Fuentes Porcel O, Perez Cabrera B, Perez Benitez F, Bustos De Abajo Mt Jean B: Melanoma metastasis to the pancreas. Rev Esp Enferm Dig 1992, 82:61-62.

9. Brodish RJ, McFadden DW: The pancreas as the solitary site of metastasis from melanoma. Pancreas 1993, 8:276-278.

10. Pereira-Lima JC, Coral GP, Bayer LR, da Silva CP: Metastasis from colon carcinoma in the dorsal pancreas of a patient with pancreas divisum: report of a case. Hepatogastroenterology 2000, 47:554-555.

11. Bachmann J, Michalski CW, Bergmann F, Buchler MW, Kleeff J, Friess H: Metastasis of rectal adenocarcinoma to the pancreas. Two case reports and a review of the literature. JOP 2007, 8:214-222.

12. Sweeney AD, Wu MF, Hilsenbeck SG, Brunicardi FC, Fisher WE: Value of pancreatic resection for cancer metastatic to the pancreas. J Surg Res 2009, 156:189-198.

13. Sellner F, Tykalsky N, De Santis M, Pont J, Klimpfinger M: Solitary and multiple isolated metastases of clear cell renal carcinoma to the pancreas: an indication for pancreatic surgery. Ann Surg Oncol 2006, $13: 75-85$
14. Zerbi A, Ortolano E, Balzano G, Borri A, Beneduce AA, Di Carlo V: Pancreatic metastasis from renal cell carcinoma: which patients benefit from surgical resection? Ann Surg Oncol 2008, 15:1161-1168.

15. Eidt S, Jergas M, Schmidt R, Siedek M: Metastasis to the pancreas - an indication for pancreatic resection? Langenbecks Arch Surg 2007, 392:539-542.

16. Karimi KM, McFadden DW: Pancreatic resection for metastatic renal cell carcinoma to the pancreas. Am Surg 2007, 73:1158-1160.

17. Sohn TA, Yeo CJ, Cameron JL, Nakeeb A, Lillemoe KD: Renal cell carcinoma metastatic to the pancreas: results of surgical management. J Gastrointest Surg 2001, 5:346-351.

18. Imanaga $\mathrm{H}$ : A new method of pancreaticoduodenectomy designed to preserve liver and pancreatic function. Surgery 1960, 47:577-586.

19. Pantuck AJ, Zisman A, Belldegrun AS: The changing natural history of renal cell carcinoma. J Urol 2001, 166:1611-1623.

20. Motzer RJ, Bander NH, Nanus DM: Renal-cell carcinoma. N Engl J Med 1996, 335:865-875.

21. Sahin M, Foulis AA, Poon FW, Imrie CW: Late focal pancreatic metastasis of renal cell carcinoma. Dig Surg 1998, 15:72-74

22. Thompson LD, Heffess CS: Renal cell carcinoma to the pancreas in surgical pathology material. Cancer 2000, 89:1076-1088.

23. Hung JH, Wang SE, Shyr YM, Su CH, Chen TH, Wu CW: Resection for secondary malignancy of the pancreas. Pancreas 2012, 41:121-129.

24. Machado NO, Chopra P: Pancreatic metastasis from renal carcinoma managed by Whipple resection. A case report and literature review of metastatic pattern, surgical management and outcome. JOP 2009 10:413-418

25. David AW, Samuel R, Eapen A, Vyas F, Joseph P, Sitaram V: Pancreatic metastasis from renal cell carcinoma 16 years after nephrectomy: a case report and review of the literature. Trop Gastroenterol 2006, 27:175-176.

26. Bassi C, Butturini G, Falconi M, Sargenti M, Mantovani W, Pederzoli P: High recurrence rate after atypical resection for pancreatic metastases from renal cell carcinoma. Br J Surg 2003, 90:555-559.

27. Reddy S, Edil BH, Cameron JL, Pawlik TM, Herman JM, Gilson MM, Campbell KA, Schulick RD, Ahuja N, Wolfgang CL: Pancreatic resection of isolated metastases from nonpancreatic primary cancers. Ann Surg Oncol 2008 15:3199-3206

28. Hirota T, Tomida T, Iwasa M, Takahashi K, Kaneda M, Tamaki H: Solitary pancreatic metastasis occurring eight years after nephrectomy for renal cell carcinoma. A case report and surgical review. Int J Pancreatol 1996, 19:145-153

29. Muranaka T, Teshima K, Honda H, Nanjo T, Hanada K, Oshiumi Y: Computed tomography and histologic appearance of pancreatic metastases from distant sources. Acta Radiol 1989, 30:615-619.

30. Ferrozzi F, Bova D, Campodonico F, Chiara FD, Passari A, Bassi P: Pancreatic metastases: CT assessment. Eur Radiol 1997, 7:241-245.

31. Maeno T, Satoh H, Ishikawa H, Yamashita YT, Naito T, Fujiwara M, Kamma H, Ohtsuka M, Hasegawa S: Patterns of pancreatic metastasis from lung cancer. Anticancer Res 1998, 18:2881-2884

32. Klein KA, Stephens DH, Welch TJ: CT characteristics of metastatic disease of the pancreas. Radiographics 1998, 18:369-378.

33. Boudghene FP, Deslandes PM, LeBlanche AF, Bigot JM: US and CT imaging features of intrapancreatic metastases. J Comput Assist Tomogr 1994, 18:905-910.

34. Ng CS, Loyer EM, lyer RB, David CL, DuBrow RA, Charnsangavej C: Metastases to the pancreas from renal cell carcinoma: findings on three-phase contrast-enhanced helical CT. AJR Am J Roentgenol 1999, 172:1555-1559.

35. Scatarige JC, Horton KM, Sheth S, Fishman EK: Pancreatic parenchymal metastases: observations on helical CT. AJR Am J Roentgenol 2001, 176:695-699.

36. Faure JP, Tuech JJ, Richer JP, Pessaux P, Arnaud JP, Carretier M: Pancreatic metastasis of renal cell carcinoma: presentation, treatment and survival. J Urol 2001, 165:20-22.

37. Yachida S, Fukushima N, Kanai Y, Nimura S, Shimada K, Yamamoto J, Sakamoto $\mathrm{M}$ : Pancreatic metastasis from renal cell carcinoma extending into the main pancreatic duct: a case report. Jpn J Clin Oncol 2002, 32:315-317.

38. Zacharoulis D, Asopa V Karvounis E, Williamson RC: Resection of renal metastases to the pancreas: a surgical challenge. HPB (Oxford) 2003, 5:137-141.

39. Mecho S, Quiroga S, Cuellar H, Sebastia C: Pancreatic metastasis of renal cell carcinoma: multidetector CT findings. Abdom Imaging 2009, 34:385-389.

40. You DD, Choi DW, Choi SH, Heo JS, Kim WS, Ho CY, Lee HG: Surgical resection of metastasis to the pancreas. J Korean Surg Soc 2011, 80:278-282. 
41. Katsourakis A, Noussios G, Hadjis I, Alatsakis M, Chatzitheoklitos E: Late solitary pancreatic metastasis from renal cell carcinoma: a case report. Case Rep Med 2012, 2012:464808.

42. Atiq M, Bhutani MS, Ross WA, Raju GS, Gong Y, Tamm EP, Javle M, Wang X, Lee $\mathrm{JH}$ : Role of endoscopic ultrasonography in evaluation of metastatic lesions to the pancreas: a tertiary cancer center experience. Pancreas 2012, 42:516-523.

43. Comunoglu C, Altaca G, Demiralay E, Moray G: Multiple metastatic renal cell carcinoma isolated to pancreas. Malays J Pathol 2012, 34:63-66.

44. Yazbek T, Gayet B: The place of enucleation and enucleo-resection in the treatment of pancreatic metastasis of renal cell carcinoma. JOP 2012, 13:433-438

45. Ramdave S, Thomas GW, Berlangieri SU, Bolton DM, Davis I, Danguy HT, Macgregor D, Scott AM: Clinical role of F-18 fluorodeoxyglucose positron emission tomography for detection and management of renal cell carcinoma. J Urol 2001, 166:825-830.

46. Majhail NS, Urbain JL, Albani JM, Kanvinde MH, Rice TW, Novick AC, Mekhail TM, Olencki TE, Elson P, Bukowski RM: F-18 fluorodeoxyglucose positron emission tomography in the evaluation of distant metastases from renal cell carcinoma. J Clin Oncol 2003, 21:3995-4000.

47. Wente MN, Kleeff J, Esposito I, Hartel M, Muller MW, Frohlich BE, Buchler MW Friess H: Renal cancer cell metastasis into the pancreas: a single-center experience and overview of the literature. Pancreas 2005, 30:218-222.

48. Masetti M, Zanini N, Martuzzi F, Fabbri C, Mastrangelo L, Landolfo G, Fornelli A, Burzi M, Vezzelli $E$, Jovine E: Analysis of prognostic factors in metastatic tumors of the pancreas: a single-center experience and review of the literature. Pancreas 2010, 39:135-143.

49. Tanis PJ, van der Gaag NA, Busch OR, van Gulik TM, Gouma DJ: Systematic review of pancreatic surgery for metastatic renal cell carcinoma. Br I Surg 2009, 96:579-592.

50. Mehta N, Volpe C, Haley T, Balos L, Bradley EL 3rd, Doerr RJ: Pancreaticoduodenectomy for metastatic renal cell carcinoma: report of a case. Surg Today 2000, 30:94-97.

51. Bechade D, Palazzo L, Desrame J, Duvic C, Herody M, Didelot F, Coutant G, Algayres JP: Pancreatic metastasis of renal cell carcinoma: report of three cases. Rev Med Interne 2002, 23:862-866.

52. Eloubeidi MA, Jhala D, Chhieng DC, Jhala N, Eltoum I, Wilcox CM: Multiple late asymptomatic pancreatic metastases from renal cell carcinoma: diagnosis by endoscopic ultrasound-guided fine needle aspiration biopsy with immunocytochemical correlation. Dig Dis Sci 2002, 47:1839-1842.

53. Butturini G, Bassi C, Falconi M, Salvia R, Caldiron E, lannucci A, Zamboni G, Graziani R, Procacci C, Pederzoli P: Surgical treatment of pancreatic metastases from renal cell carcinomas. Dig Surg 1998, 15:241-246.

54. Kassabian A, Stein J, Jabbour N, Parsa K, Skinner D, Parekh D, Cosenza C, Selby R: Renal cell carcinoma metastatic to the pancreas: a singleinstitution series and review of the literature. Urology 2000, 56:211-215.

55. Ghavamian R, Klein KA, Stephens DH, Welch TJ, LeRoy AJ, Richardson RL, Burch PA, Zincke H: Renal cell carcinoma metastatic to the pancreas: clinical and radiological features. Mayo Clin Proc 2000, 75:581-585.

56. Law CH, Wei AC, Hanna SS, Al-Zahrani M, Taylor BR, Greig PD, Langer B, Gallinger S: Pancreatic resection for metastatic renal cell carcinoma: presentation, treatment, and outcome. Ann Surg Oncol 2003, 10:922-926.

57. Varker KA, Muscarella P, Wall K, Ellison C, Bloomston M: Pancreatectomy for non-pancreatic malignancies results in improved survival after RO resection. World J Surg Oncol 2007, 5:145.

58. Schauer M, Vogelsang H, Siewert JR: Pancreatic resection for metastatic renal cell carcinoma: a single center experience and review of the literature. Anticancer Res 2008, 28:361-365.

59. Konstantinidis IT, Dursun A, Zheng H, Wargo JA, Thayer SP, Fernandez-del Castillo C, Warshaw AL, Ferrone CR: Metastatic tumors in the pancreas in the modern era. J Am Coll Surg 2010, 211:749-753.

60. Gardini A, Morgagni P, Milandri C, Riccobon A, Ridolfi R, La Barba G, Saragoni L, Amadori D, Garcea D: Pancreatic resection for metastases from renal cancer: long term outcome after surgery and immunotherapy approach - single center experience. Hepatogastroenterology 2012, 59:687-690.

doi:10.1186/1477-7819-11-289

Cite this article as: Hoshino et al.: Pancreatic metastases from renal cell carcinoma: a case report and literature review of the clinical and radiological characteristics. World Journal of Surgical Oncology 2013 11:289.

\section{Submit your next manuscript to BioMed Central and take full advantage of:}

- Convenient online submission

- Thorough peer review

- No space constraints or color figure charges

- Immediate publication on acceptance

- Inclusion in PubMed, CAS, Scopus and Google Scholar

- Research which is freely available for redistribution 